\title{
An Alternative History of Technology in South Asia: The Unknown Viśvakarmās of Colonial Bengal
}

\author{
Suvobrata Sarkar* \\ Assistant Professor, Department of History, Rabindra Bharati University, Kolkata.
}

(Received 03 February 2019; revised 24 November 2019)

\begin{abstract}
Why an alternative history of technology in South Asia? If one explores the literature, which has gathered momentum since the 1990s, it has thus far focused on the renowned scientists, technologists, doctors and other elite actors while dealing with Indian contribution to modern techno-science. Of course, they are important. But if we study the journals, periodicals, tracts, monographs written in Indian languages in the 19th and early 20th century, one can get numerous examples of indigenous efforts in the field of technology. These men excelled as "engineers" without institutional training in engineering but seldom get the desired intellectual limelight. They were the unknown viśvakarmās. The use of the term 'viśvakarmā' here is purely metaphoric, not to promote any religion or ideology. For a better understanding of the Indian appropriation of modern technology, we need to include them in the existing literature. This is a humble initiative to present the histories of a few of them and a homage to Siddhartha Ghosh who originally started the project in the early 1990s, but was unable to complete due to his sad demise.
\end{abstract}

Key words: Alternative history of technology, Modern viśvakarmās, Subaltern technologists.

\section{Introduction}

In Hindu theology, the goddess of learning, Sarasvati, enjoys a higher status than the god of technology, Viśvakarma . Traditionally the intellectual cream of the society often looked down upon technology as an inferior form of activity. The scholastic class and artisans lived in exclusive social and cognitive worlds and thus circulation of knowledge was not possible. The Indian social structure, identified by Indian luminaries, was responsible for the cleavage between mental and manual work and the resultant stagnation. This was entirely opposite to the practice of Western Europe, including Britain. There the artisans enjoyed a higher status and when engineering education was introduced, they were the beneficiaries of that. It helped them to become modern engineers. The outcome

DOI: $10.16943 / \mathrm{ijhs} / 2020 / \mathrm{v55i1} / 152342$

*Email: suvobrata.jnu@gmail.com was such stalwart like James Watt. In India, on the contrary, the 'class' and the 'mass' lived in two air-tight compartments - thus the probability of exchange of ideas was almost nil.

If one scans the vernacular publications (memoirs, journals, periodicals, tracts), of the late 19th and early 20th century; they can get innumerable chronicles of selfmade viśvakarmās who excelled in the field of technology. The legends of Goluk Chunder, the first Indian engineer; Shiv Chunder Nundy, electrical engineer of the telegraph fame; Kalidas Moitra, the first Bengali writer on technical subjects; Jawaharlal Dhar, self-styled electrician and inventor; Sitanath Ghosh, architect of Magnetic Healer; Bepin Behari Das, manufacturer of the first indigenous motor car; Jogesh Chandra Ray, self-made technologist, only illustrates the point that not only the foreign ruler but also contemporary intellectual class was equally accountable for not only underrating, even ignoring them 
altogether. That's why probably we are unable to produce a James Watt. This is also a humble effort to present the untold chronicles of a few of these 'Subaltern Technologists'.

\section{Subaltern Technologists}

Examining the world of popular healing in South Asia, two scholars recently look at the way that it is marginalized by the state and medical establishments while at the same time being very important in the everyday lives of the poor. They analyze a world of 'subaltern therapeutics' that both interacts with and resists state-sanctioned and elite forms of medical practice (Hardiman and Mukherji 2012). The subject of a subaltern history of medicine, they argue, seeks to represent whatever is marginalized within that academic field of knowledge. It might be possible then to better forge a link between scientific ideas and its technological translation. In this context, it is perhaps fitting that we begin here with a discussion of non-Western traditions of technology and the choices before them during our period of discussion. In many of these societies science traditionally enjoyed a higher status than most forms of technology. Traditional Indian society was also not an exception - where scholar-gentry and artisans lived in exclusive social and cognitive worlds and where problems of application are not shared between such groups, but only within them (Nandy 2010, pp. 85-86). In traditional society science as a part of philosophy resembled more with the erudite - the Brahmins. Technology, despite its place in the cosmology, was confined among the manipulators of things - the artisans (Bose 1921, p. 14). ${ }^{1}$ Did colonial intervention merely mark the earlier fault-line between hand and mind? The first volume of the Subaltern Studies, edited by Ranajit Guha, was published with a provocative opening statement: "The historiography of Indian nationalism has for a long time been dominated by elitism - colonialist elitism and bourgeois-nationalist elitism" (Guha 1982, p. 1). The subaltern historians wanted to provide

${ }^{1}$ P. N. Bose, the great geologist, observed in the early 20 th century, "Among the Hindus, Manu condemned the institution of huge machinery as a sin. Plain living and high thinking, poverty and culture (especially ethical and spiritual culture) have from remote antiquity been the only passports to distinction and veneration among them. Viśvakarmās, the divine patron of arts in India, receives homage only from artisans, and he is in no way superior to $M \bar{a} y \bar{a}$, the architect of the Dānavās." 'an alternate narrative' of the Indian freedom movement unlike earlier which only emphasized the contributions of 'great men' - Gandhi, Nehru, Jinnah, and sometimes Bose. Subaltern Studies Collective rejected this approach and attempted to tell an alternative story, one of 'bottomup' contributions to Indian history and society. However, most recently, Kristin Plys argues what became known as Subaltern Studies has downplayed the empirical role of the working class. One of the reasons for this underemphasis, according to her, is a specific and culturally essentialist mode of appropriating the work of E. P. Thompson, Carlo Ginzburg, and others, who are declared influences on Subaltern Studies (Plys 2019). Interestingly the historiography of science and technology in South Asia is always top-heavy- the accounts of few renowned Indian scientists, technocrats and science enthusiasts (Kumar 2006; Anderson 2010; Phalkey 2013; Chowdhury 2016). Even we have very limited studies on the engineering profession and subsequent industrialization in the colonial Indian context (Ramnath 2017). Of course, the scientists, engineers, and doctors, products of institutional training, are important to understand Indian appropriation of the Western technoscientific knowledge. During the Swadeshi era, there were serious discussions and debates among the erudite regarding the role and place of Indian artisans in the modern technical education (Raina and Habib 2004, pp. 84-130). However, gradually 'Academic Engineering' grabbed all the limelight. There also existed substantial indigenous efforts, without any intellectual limelight, in the field of technology. The achievements of these men devoid of formal technological training, whom we hesitantly name 'Subaltern Technologists' (unknown viśvakarmās), deserve mention.

\section{Goluk Chunder, the first Indian engineer}

This 'House of Unknown Fame' is long and the luminaries can be found in the early 19th century itself. Amitabha Ghosh has identified Goluk Chunder, a Bengali blacksmith of Titagar, as the first Indian engineer if we abide by the original significance of the word 'engineer' (Ghosh 1994, pp. 63-75). Engineer was a post-James Watt connotation and literally meant one who builds or erects steam engines. Goluk Chunder did build a steam engine in 1828. In Serampore, the first self-contained in- 
dustrial complex of Bengal, paper manufacture received a real breakthrough in 1820 with the introduction of steam power. $^{2}$ Many contemporary Europeans tried hard to make a prototype of the imported engine. But it was Goluk Chunder who was ultimately succeeded to copy it. The steam engine made by him was put on display during the Annual Exhibition of the Agri-Horticultural Society at the Town Hall of Calcutta in January 1828. The Calcutta Gazette reported on 17 January:

A Curious model of a Steam Engine, made by Goluk Chunder, Blacksmith of Tittaghur, near Barrackpur, without any assistance from European artists, was likewise exhibited; and although not coming within the immediate sphere of the society's exertions was considered so striking an instance of native ingenuity and imitative skill as to deserve encouragement. A donation of fifty rupees was, therefore, presented to the ingenious Blacksmith. ${ }^{3}$

Was there any practical utility of the steam engine made by Goluk Chunder? George Smith, the biographer of William Carey mentioned it: “...the steam engine was useful for irrigation of lands made upon the model of a large steam engine belonging to the missionaries at Serampore" (Smith 1885, p. 231). But unfortunately, nothing more about the first Indian engineer is known.

Thus, the steam engine, in those days an imported technological innovation from Britain, produced ripples in the minds of the local people. And in the early 19th century itself one Goluk Chunder, without any knowledge of modern mechanics, was able to make a proto-type of steam engine successfully. Electricity also, another technological innovation, did not remain a virgin very long! In the age of industrial revolution to cope with the ever-increasing need to speed up communication side by side steamships

\footnotetext{
${ }^{2}$ The 12 horse-power steam engine of Thwaites Hick \& Rothwells imported from England was an object of wonder. One contemporary journal reported: "Even the Steam Engine although it has been in operation for four years does not cease to draw crowds of natives to inspect it from week to week, who,...quietly inspect it at leisure, and departed convinced that all knowledge was not engrossed by their fore-fathers..." Calcutta Gazette, 27 May, 1824; quoted in Anil Chandra Das Gupta (ed.), The Days of the John Company: Selections from Calcutta Gazette 1824-1832, West Bengal Government Press, Calcutta 1959, pp. 13-15.

${ }^{3}$ Calcutta Gazette, 17 January, 1828; quoted in ibid, pp. 272-273.
}

and railways, the new science of electricity found the first practical and large-scale application in the telegraph. It was with the introduction of the electric telegraph system that the profession of electrical engineering came into existence (Bernal 1954, p. 390). The first Indian electrical engineer Shiv Chunder Nundy came from the field of electric telegraph.

\section{Shiv Chunder Nundy of telegraph fame}

Shiv Chunder, at the age of 22, joined the Refinery Department of the Calcutta Mint in 1846. His rise in the professional career shows that he was entirely a self-made man. His technical aptitude came to the notice of W. B. O'Shaughnessy, the chemical examiner of the Mint, and Nundy was selected as his 'personal assistant'. Together they carried out several experiments in O'Shaughnessy's laboratory (Ghosh 1988, p. 48). When in 1851 the Company Bahadur authorized the construction of the first telegraph line in India and selected O'Shaughnessy to lead the task, he immediately placed Nundy as 'in-charge' of the assignment. Thus, the mint-man became a telegraphman, a transformation that would last the rest of his life. In the very next year work for the 21 miles long, first section was completed and Nundy's was closely associated with the project. It was Shiv Chunder who sent the inaugural message from Diamond Harbour, received in Calcutta by Lord Dalhousie and O'Shaughnessy (Shridharani 1953, p. 13). Immediately afterward, Nundy was appointed as 'Inspector' in-charge of the line. He had also to instruct and train other signallers. He was afterward given the additional charge of the Post Office at Diamond Harbour. Subsequently, he constructed about 900 miles of lines, from east Barrackpur to Allahabad, from Benares to Mirzapur, from Mirzapur to Seonee and from Calcutta to Dacca (Ghosh 1953, pp. 107-114). ${ }^{4}$ Such responsibilities are enough to secure Nundy the distinction of an engineer proper.

During the turmoil of 1857, Shiv Chunder was incharge of the headquarter Calcutta and in order to secure

\footnotetext{
${ }^{4}$ During the construction of the Calcutta-Dacca line, it became necessary to lay 7 miles of underwater cable cross the River Padma. With no steamer company willing to lend their vessels for the work at less than Rs. 10,000, a determined Nundy got it done by hiring country fishing boats.
} 
the communication between Calcutta and Bombay, he laid down a portion of the alternative line from Mirzapur to Seoni via Jubbulpur (Shridharani 1953, p. 15). Nundy became an Assistant Superintendent of the Indian Telegraph Department (1866) and retired on a special pension in 1884, the year in which he was made an Honorary Magistrate. He was awarded the title 'Rai Bahadur' in the preceding year. ${ }^{5}$

\section{Kalidas Moitra, the first Bengali writer on technological themes}

Many Indians made some significant attempts to diffuse and disseminate knowledge about technology in the public sphere in the Indian languages. Electric telegraph and railways perhaps first captured the imagination of the Bengali intellectuals in the 19th century. One Kalidas Moitra of Serampore first wrote two separate treatises on these technological innovations in Bengali as early as 1855 (Moitra 1855). Apart from original works on the telegraph and railways, he also published on the principles of anatomy and physiology (Moitra 1855). Moitra, in his book on telegraphy, claimed that though several authors wrote on electricity and chemistry in Tattvabodhini Patrikā, Vividhārtha Samgraha and Satyapradip Patrikā, his monograph was the first attempt in Bengali to cover the entire subject of electricity (Figure 1). He provided guidelines for experiments like principles of magnetism and chemical reaction using household items. He named telegraph stations as aḍ̂̄̄s or 'chatting spaces', and described O'Shaughnessy's Single Needle signaling instrument at length, probably in the hopes of Indian replication (Moitra 1855, pp. 120-131). Moitra provided a preliminary outline of systems of signaling in Bengali, along with the English. He also gave here elaborate discussion on the Puranic or classical Indian time and Western time. Arguing for the superiority of the Western division of the day into 24 hours, he provided a guide to both Western and Indian time calculations as well as homogenizing time calculation (Moitra 1855, pp. 150-153). Although an ardent followers of Western technology, one can find a high dose of revivalist tenor in some of Moitra's writings. For example, he attempted to prove that ancient Indians

${ }^{5}$ The Statesman commented on 25 April 1902, "A Rai Bahadurship seems to have been a poor reward for his excellent services."

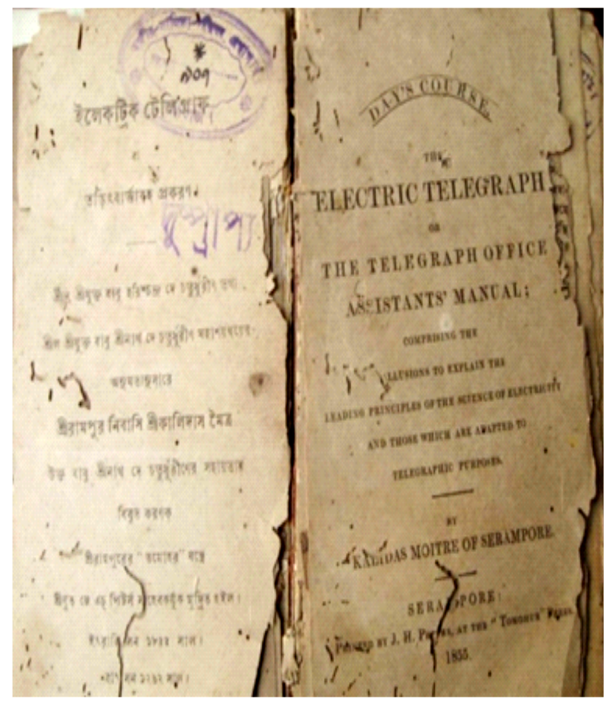

Figure 1 Moitra's Electric Telegraph ba Taritbartabaha Prakaran (1855). Source: Bangiya Sahitya Parishad Library, Kolkata.

used steam power in his Baspiya Kal O Bhartiya Railway (Moitra 1855, p. 4). Thus he constructed his argument based on many early 19th-century Indian nationalists that ancient Indian culture was the amalgamation of both spiritual knowledge and scientific truths. At the same time, Moitra was aware of the exploitative nature of colonialism and argued the British state's strategic need to transport troops rapidly was behind the growth of railways in India (Moitra 1855, p. 48). He admitted honestly that he borrowed various technicalities of steam engines from several English works. For Moitra machine was equal to modernity, and, telegraph and railways were the best example of that. He urged his countrymen to learn a European concept that time was money. Deep Kanta Lahiri Choudhury perhaps rightly remarks that Kalidas Moitra was a curious combination of "early nationalist egotism and conservative radicalism" (Choudhury 2010, p. 26).

\section{Sitanath Ghosh, the self-made inventor}

Sitanath Ghosh of Jessore manufactured an air pump and power loom exhibited in Hindu Mela in the 1870s. The young Sitanath entered the Calcutta Medical College for his aptitude in scientific pursuits but was unable to complete his study due to ill health. He privately studied elec- 
tricity and later joined as the editor of the Hindu Patrikā from Calcutta in which he published many scientific papers (Samaddar 1912, pp. 237-239). The fifth session of the Mela (1871) was significant from the point of view of technological innovation. Here Sitanath for the first time demonstrated his cotton spindle by which yarn was produced and twisted mechanically in three places without manual effort at each turn though the thread lacked uniform thinness. He also showed his loom, but it was not a finished manufacture at that stage. ${ }^{6}$ Sitanath also delivered a lecture on various issues of science and technology even before he demonstrated his inventions. In fact, he made his first appearance on the platform of the National Society which was created from the fourth session of the Mela in 1870, in concurrence with it (Palit 2006, p. 75). The first lecture was given by Sitanath on machinery about his new air pump and power loom. The latter could produce the work of four persons by the simple operations of one operator. On the same platform, he gave his speech on electricity (Bagal 1945, p. 40). ${ }^{7}$ Impressed with his lectures on 'Electricity and Magnetism' at the National Society, Debendranath Tagore offered Sitanath the editorship of the prestigious journal, Tattvabodhin̄ Patrikā in 1872. In the subsequent years, he regularly contributed on electricity in that journal. ${ }^{8}$

In the tenth session of the Hindu Mela (1876), Sitanath demonstrated his cotton-weaving machine and a loom which could be run by draught animals, steam or manual labour. The first was an improvement of carakhā and produced treble the amount of yarn done by the latter. The loom can produce in a single effort over twenty yards of cloth. ${ }^{9}$ The cloth was not yet of fine quality but in future would compete with Manchester given due encouragement (Bagal 1945, p. 40). The weaving machine made him famous. Many wealthy persons, including the Rani of Betia, offered a huge amount of money to buy his weaving machine. But Sitanath was determined not to sell it. He also invented a wheat pounding machine, a mechanical

\footnotetext{
${ }^{6}$ Sulav Samachar, 21 February, 1871; Amrita Bazar Patrika, March $2,1871$.

${ }^{7}$ Sitanath himself said: "In the summer of the year 1871, being requested by some of my friends, I delivered two successive addresses at the National Society's meeting in the Calcutta Training Academy's Hall on the ideas I conceived about the electrical and magnetic importance of the said practices."

${ }^{8}$ For example, Sitanath Ghosh, 'Tarit bishoyok jnan', Tattobodhini Patrikā, Vol. 8, No. 2, Issue 352, Pous 1794 Śaka (1872), p. 148.

${ }^{9}$ Sadharani, 27 February, 1876.
}

plough which could be drawn with the help of one bullock and a mechanized boat. His other inventions were writing and press ink. He gave the formula to his friend Amrita Lal Roy who later became well-known using the formula as A. L. Roy's ink. Another invention, the scientific amulet was given to one Brajamohan Kar for marketing and he also made a good business out of it (Samaddar 1912, p. 241). Inspired by the concept of the Hindu Mela, Sitanath organized an annual agricultural and educational fair in his native village Roygram, Jessore. There also he demonstrated his technological skills-that time in the form of telegraph lines set up from the riverfront to the fair site to welcome the dignitaries (Samaddar 1912, p. 241).

Sitanath's greatest scientific achievement, in his opinion, was the Magnetic Healer, which he described in his book on Medical Magnetism. Here he even depicted himself as the founder of Electropathy or Magnetic System of Treatment in India. He derived the principle from the daily prayer (âhnik mantra) of the Hindus and from the Viśṇu Purāna. The trident over temples was based on the theory of magnetism to prevent their collapse from lightning strikes. "It has been found that", wrote Sitanath, "...the human body is a magnetizable object though far inferior to iron and steel”. In 1880, he opened his chamber at Mechhua Bazar Street, Calcutta and started treatment of patients by electricity and magnetism. He claimed that “...every description of indisposition known is partially or entirely removed as it is light or serious" (Bagal 1945, p. 40). ${ }^{10}$ As we know that technology was technique informed by scientific knowledge, Sitanath was a technologist in its true sense - for he did not rest satisfied with the theoretical principles of electricity alone, he applied that knowledge to invent his apparatus Magnetic Healer.

\footnotetext{
${ }^{10}$ Sitanath's Magnetic Healer, one small and one big ( $2 \mathrm{ft}$. and $4 \mathrm{ft}$.), was composed of 6,000 and 10,000 ft. of copper wire passing through a wooden frame cushioned with mat and jute, wax and leather linings. They had brass hooks at the end of which were attached the wires of the galvanic battery for creating the magnetic field. The patient would be made to lie on this platform so that electric waves passed through the body. Sitanath Ghosh, Medical Magnetism, quoted in Jogesh Chandra Bagal, Jatiyatar Nabamantra O Hindu Melar Itibritta, op.cit, p. 219.
} 


\section{Jogesh Chandra Ray: A rare genius}

Another example of technological ramification of scientific principles is Jogesh Chandra Ray, lecturer of science at the Ravenshaw College, Cuttack (Figure 2). He always insisted on the practical demonstration of theoretical knowledge while teaching and tried to keep the college laboratory up-to-date for the benefits of students. For better instruction in physical sciences, he even manufactured various instruments (Chattopadhyay 2009, p. 18). Jogesh Chandra was a prolific writer and contributed to the leading journals of Calcutta - both English and Bengali. He also realized a serious lacuna of science teaching in the Indian colleges and schools, i.e., the absence of good quality books in Bengali. So, he concentrated on writing Bengali books on science subjects for students. ${ }^{11}$

Jogesh Chandra was a multi-talented character. From scientific subjects to literature, his canvas was vast. He was elected Fellow at the Royal Microscopical Society (1901) and the Royal Astronomical Society (1902). One can devote an entire treatise on him! Here we will discuss Jogesh Chandra's accomplishment in the field of technology. He always tried to apply his scientific aptitude for the betterment of the society. His inquisitiveness dragged him towards different branches of knowledge- the first perhaps was fabric-printing. From a casual reading of the Journal of Indian Art, Jogesh Chandra grew his interest in the subject and devoted almost two years experimenting with colours (Ray 1892, pp. 177-183). His other trial was pencil-making. This episode is a bit interesting! During the swadeshi era many enterprising Indians worked out schemes for industrial ventures - some saw light of the day and others sank without moving a single stone. One of the reasons for failure was the lack of technical knowledge of that filed. ${ }^{12}$ In 1906 Jogesh Chan-

\footnotetext{
${ }^{11}$ Prof. Jagadish Chnadra Bose once remarked: "From what I have seen the elements of Physics and Physiography in Bengali by Babu Joges Chandra Ray, M. A., I found them in many respects superior to other books of the same class. The method of treatment is commendable and the explanations clear and concise. The woodcuts are excellent. I trust they would be found of great service to those for whom they are intended." Quoted in Jogesh Chandra Ray, Atmajebani, Anandakumar Roy, Bankura 2002, p. 298.

${ }^{12}$ But despite the absence of technical knowledge, the patrioticminded Indians were determined to start various industries. Many wealthy Indians invested huge amount of money without knowing anything about business or scientific production. To take advantage of the situation many quacks emerged during early 20th cen-
}

dra bought shares of a swadeshi pencil-making company and suffered a huge loss due to the reason already stated. With sheer ignorance, the company selected 'cedarwood' whereas for pencil-making the necessary ingredient was 'bastard wood'. At this Jogesh Chandra tried his hands in pencil-making with the assistance of Nilmony Sadhukha, lecturer of mathematics at his college. ${ }^{13}$ This was for fun only, without any intention of profit-making. After a few days of experiment, he realized that pencil-making was possible and that too like the imported ones.

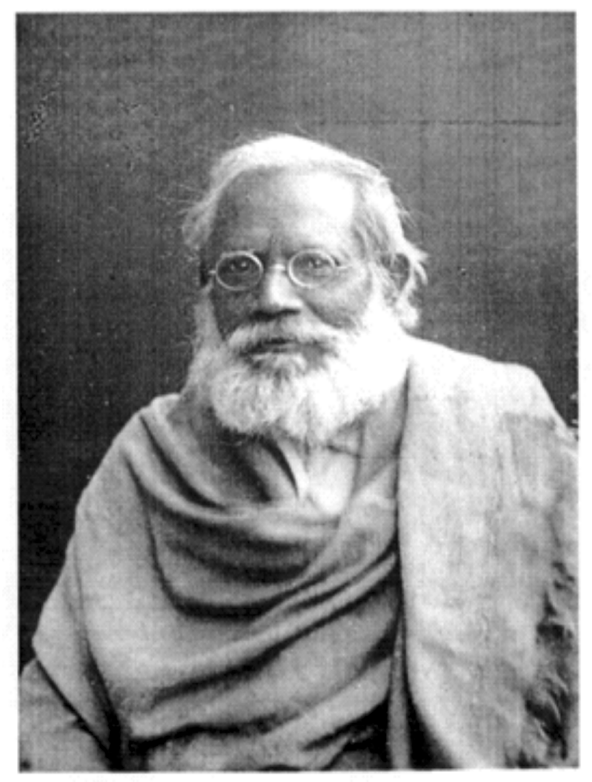

Figure 2 Jogesh Chandra Ray (1859-1956) Source: Jogesh Chandra Ray, Atmajebani (An Autobiography).

Jogesh Chandra's major invention was Wind-mill which made him famous. He published the result of his research in the Sāhitya Parișad Patrikā and it demonstrated his engineering skills (Ray 1914, pp. 81-96). In the year 1923, he applied for the patent of two of his appliances one was 'an improved hand mill' and another was 'an improved lift pump for liquids'. The government sanction came in the very next year. His hand-mill consisted of a

tury. They pretended as specialists and used to seek the patronage of the wealthy class. The result was obvious-after few days they disappeared. Perhaps the best possible depiction of this era is Troilokkyanath Mukhopadhyay, Damru-Charit,: New Age Publisher Pvt.. Ltd, Fifth Edition, Kolkata, 2009 (First published in 1923), pp. 98104.

${ }^{13}$ Jogesh Chandra Ray, Atmajebani, op.cit, p. 178. 
stationary upper stone and a revolving lower stone, with an arrangement for maintaining a gap between the stones, which could be regulated at will. In the ordinary grinding mill used in Indian households, the lower stone remained fixed while the upper stone rotated. Splitting the pulses without pulverizing was difficult to perform by the old grinding machine which tended to crush the pulses rather than to split. This difficulty, Jogesh Chandra claimed, had been overcome in his improved hand mill entirely. ${ }^{14}$

Jogesh Chandra's another feat, his improved lift-pump for liquids, was perhaps more interesting. The following description, quoted from the testimony of the inventor to the Patent Office, ascertains the nature of his invention:

This invention relates to a lift pump which is capable of raising water from any depth and which can be worked by means of levers operated by foot, or by hand, or jointly by foot and hand, or with the addition of a suitable gear of bullock power. Ordinary suction pumps cannot raise water from depths below twenty-five feet. This defect has been overcome in my invention by using a long pump barrel, of which one end is submerged in water and the other end extends right up to the delivery point. A long-stroke piston is used and the portion of the barrel below the piston functions as an ordinary suction pump, while the portion above acts in the manner of a force pump. Another defect in common hand pumps is the rapid wear of the pump bucket or hide cup. This has been overcome in my invention by dispensing with the hide cup or any other packing for the piston and by using a loose piston which is long enough to prevent any considerable side-slip or leakage past it of water. Leather or hide is not necessary for any of the working parts, which is an advantage... ${ }^{15}$

\footnotetext{
${ }^{14}$ Government of India, The Patent Office, 1 Council House Street, Calcutta; Specification No. 9355, 31st May 1923, Accepted 4th February 1924; An Improved Hand Mill by Joges Chandra Ray, a Government Pensioner, residing at Bankura, Bengal; Quoted in Jogesh Chandra Ray, Atmajebani, op.cit, p. 239.

${ }^{15}$ Government of India, The Patent Office, 1 Council House Street, Calcutta; Specification No. 9354, 31st May 1923, Accepted 4th August 1924; An Improved Lift Pump for Liquids by Joges Chandra Ray, a Government Pensioner, residing at Bankura, Bengal; Quoted in Jogesh Chandra Ray, Atmajebani, ibid, p. 243.
}

A man with such technological inclination must have clear perceptions of technical education also. Yes, on several occasions Jogesh Chandra demanded better facilities to train the 'Architects and Engineers' (Ray 1902, pp. 674687, 760-771). We needed such education which could enhance the resources of our country. He realized the inherent gulf between the mainstream education and technical training - for former was for Brahmins whereas the latter meant for the Sudrās. Jogesh Chandra ridiculed the popular demand for technical education which according to him was without any clear conception about the definition of such education (Ray 1902, p. 685). Mere training in pottery, carpentry, etc. was not enough. The industrial application of technical knowledge was necessary. There was little effort to increase the inventive capacity of our students in engineering colleges. Behind the achievements of Germany and America in the modern world were only their inventive skills. Jogesh Chandra knew that Newton or Darwin rarely appeared, but at least we could manufacture an Edison or a Rontgen at our country (Ray 1902, p. 770). He continued, the lack of adequate industry to absorb the science students was an acute problem of our country. The only successful industrial application of scientific knowledge, Jogesh Babu pointed out, was a pharmaceutical works (Bengal Chemical and Pharmaceutical Works Ltd). He was upset with the trend of foreign technical training which he thought was unable to alter the industrial scenario. Jogesh Chandra reminded us two points - technical education alone was not the gateway to industry, and without knowing the country no one could succeed to run an industry successfully with his foreign degrees of technology (Ray 1915, pp. 127-141). It is evident from his autobiography that Jogesh Chandra Ray was a well-known figure of early 20th century Calcutta. He had personal contact with the contemporary intellectuals - Rabindranath Tagore, Jagadish Chandra Bose, Gooroo Das Banerjee, C. V. Raman, Prafulla Chandra Ray - to name of the few. He was also a regular contributor to various prestigious journals of the time. The Calcutta University conferred him honorary D.Lit. degree in 1956. In that sense, Jogesh Babu was the most privileged person in the list of our 'Subaltern Technologists'. But as the word subaltern suggests he remains absent in the academic discussion on the Bengali attainments in modern techno-science even today. 


\section{Bepin Behari Das: An Indian Edition of Henry Ford}

The last luminary of our 'House of Unknown Fame' is Bepin Behari Das, a self-taught mechanic, who can safely be termed as the first builder of an Indian motor car. When motor cars first appeared in early 20th century Calcutta, the famous coach-builders of the time like Steuart and Co. or Dykes and Co. found little difficulty in reorienting their expertise and built elegant cars bodies. ${ }^{16}$ But these initiatives entirely depended on foreign technologies and expertise. Indian engineers were not ready yet thinking in terms of car manufacturing. But a miracle happened and the protagonist was a self-taught mechanic deprived of any advanced training in technology. Bepin Behari Das, working in a small shed near BallygungeBondel Road crossing, Calcutta, built all the components of a car including its body and chassis except for tyres, spark plugs, carburetor, and magneto. 'Swadeshi', as named by its builder, was a ' $15 \mathrm{hp}$. L-head 4-cylinder 5seater and 4 door touring model car' (Figure 3). ${ }^{17}$ Bepin Behari sold his first car, Swadeshi, to Benaras Hindu University in 1931. One D. P. Khaitan, councillor of Calcutta Corporation noted in 1933 that the car was still running and was used by Pandit Motilal Nehru and Pandit Madan Mohan Malaviya. ${ }^{18}$ Thus the first car manufactured by an Indian was used by the leading Indian nationalists of the time!

The Calcutta Corporation entrusted Bepin Behari with the task of building a second car for them at a cost of Rs. 3000. Arrangements were made to pay him Rs. 300 per month as advance for six months on the condition that '...any defect being disclosed in any part or parts of the car during the period of two years, he will examine the same and should any fault be due to defective material or workmanship, he will repair the defective part or supply a new part in place thereof free of charge. ${ }^{, 19}$ However, he would not be held responsible for tyres, tubes, speedometer, or any electrical equipment not manufactured by him. The car would be 12 1/2 feet in length for which 'an imported

\footnotetext{
${ }^{16}$ Arthik Unnoti, Vol. 2, No. 1, Baishak 1334 B. S. (1927), p. 13.

${ }^{17}$ The Calcutta Municipal Gazette, Vol. XV, No. 15, March 19, 1932, p. 698.

${ }^{18}$ 'The Swadeshi Motor Car', The Calcutta Municipal Gazette, Vol. XVI, No. 1, June 3, 1933, p. 56.

${ }^{19}$ The Calcutta Municipal Gazette, Vol. XV, No. 24, May 21, 1932, p. 1078.
}

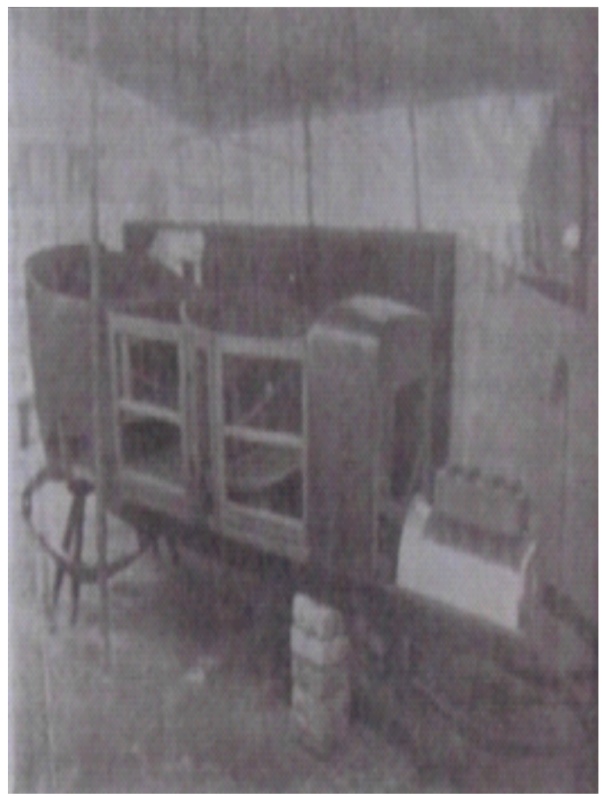

Figure 3 The bonnet of the car, Swadeshi, made by Bepin Behari. Source: The Calcutta Municipal Gazette (1933).

car would cost Rs. 5 or 6 thousands'. ${ }^{20}$ It is interesting to note that when the delivery of the car was little delayed almost all the councillors expressed serious doubts regarding the capability of Bepin Behari and were convinced of misuse of public money. Luckily, he was supported by the then Mayor of the Corporation, Santosh Kumar Basu, and few others and the project continued. ${ }^{21}$

Bepin Behari successfully built his second car within the stipulated time and proved again his technological skills. After the first trial run of the 'Swadeshi Motor Car' on the road of Calcutta, the editor of Advance happily noted in 1933, “...last week an event, which will perhaps stand out as epoch-making in Indian industrial history, took place, comparatively quietly when the first motor car manufactured in Bengal by a Bengali, was passed by the police for registration and awarded the number 35977. The car did up to $35 \mathrm{mph}$. and the ease in steering and its good acceleration were praised by the correspondent."22 But Bepin Behari's endeavour found little appre-

\footnotetext{
${ }^{20}$ Ibid.

${ }^{21}$ 'Swadeshi Motor', Banik, Vol. 7, No. 2, Jaistha 1339 B. S. (1932), p. 42 .

${ }^{22}$ Quoted in 'The Swadeshi Motor Car: Trial Runs in Calcutta', The Calcutta Municipal Gazette, Vol. XVI, No. 6, November 18, 1933 pp. 1105-7. See also 'Bangali lirmito motorcar' (Motorcar made by a
} 
ciation and patronage. He built another car for Gwalior State which ran satisfactorily for many years (Ghosh 1953, p. 72). He was engaged with another car-making project at the time of his death in 1938. Bepin Behari Das was only 55 then. ${ }^{23}$ His garage was not very far from Jadavpur where another indigenous experiment was going on to make Indian youths technologically self-sufficient - the National Council of Education and its progeny College of Engineering and Technology (modern-day Jadavpur University) (Sarkar 1946). But one cannot find any mention of Bepin Behari in any transaction of the college. His example reveals that not only the British government but also the Indian erudite thought little of the people below in the technological hierarchy created by the modern state.

It would be wrong to assume that the persons dealt here with were the only examples of creative aptitude in the field of technology in India. One can give several instances where the humble technologists toiled their hands far away from the intellectual limelight. Modern viśvakarmās were scattered all over the country. But one must know the local languages to read the contemporary texts to tap their attainments.

\section{Conclusion}

Our study reveals that Indian attainment in the field of technology was not confined in the so-called educated strata of society. Institutional training does not always lead to technological proficiency. So, we have numerous semi-literate or illiterate viśvakarmās with their distinctive accomplishments in techno-science. ${ }^{24}$ How many of

Bengali), Banik, Vol. 8, No. 9, Pous 1340 B. S. (1933), p. 285.

${ }^{23}$ A perfunctory obituary in The Calcutta Municipal Gazette concludes with the comment: "He was undoubtedly justified in his claim to have been the only Indian manufacturer of a car in this country." 'Mr. B. B. Das dead', The Calcutta Municipal Gazette, Vol. XIX, No. 7, April 9, 1938, p. 1107.

${ }^{24}$ The blacksmiths were the principal architects of the cutlery industry of Kanchannagar, Burdwan district, in the 19th century. One Premchand Mistri established a small workshop and attained highest artisanal genius without academic training in the field. Once he offered some unique surgical knives, produced at his workshop, to a civil surgeon of Burdwan. The Indian doctor was highly impressed by Premchand's craftsmanship and personally arranged to send those products to an international exhibition in London in 1889. Premchand was awarded with a medal and certificate by the exhibition committee. Earlier, the Journal of Indian Art (1886), published from London, mentioned his high-quality knives and scissors, and the acceptability of those products at the Government Stationary Office. Achintya Ku- us know about Goluk Chunder or Shiv Chunder Nundy? Without training in the science of electricity, Nundy excelled in the field of electric telegraph which was considered as high-level technology in those days. Kalidas Moitra of Serampore wrote two separate treatises in Bengali on electric telegraph and steam railways (1855), and that too, in technical style. Moitra was the first writer in Bengali on the complicated issues of technology. The case of Bepin Behari Das, a self-taught mechanic, was equally interesting.

The 'House of Unknown Fame' is long. ${ }^{25}$ They need the individual attention of the scholars. But unfortunately, these subaltern technologists remain hidden and forgotten. Even the contemporary elite of Indian society were reluctant to acknowledge them. Except Jogesh Chandra Ray, who himself belonged to that section, others never received their due recognition. In Western Europe, the Industrial Revolution witnessed the emergence of millwright from the village carpenters, blacksmiths, and wheelwright. This was the transitional stage from the traditional techniques to modern engineering. How can one forget that James Watt, the inventor of the steam engine, began his career as a self-taught skilled artisan? But technical education did not in any way help the Indians as it did their counterparts in Western Europe. On the contrary, the system of technical education created a huge difference between the 'Subaltern Technologists' and the 'Babu Engineers'. So, there was a delink between the intellectual cream of the society (mind) and the ground-level technicians (hands). The result was obvious - disjunction in the knowledge circulation. In the future, India would produce world-famous scientists, but not engineers-inventors, like James Watt or Thomas Edison. Thus, scholars have been researching Jagadish Chandra Bose (Dasgupta, 2018), the great Indian physicist, but seldom discuss the careers of Putiram, Jamshed, Barik

mar Dutta, 'Indigenous Technique and Artisanal Works: Blacksmiths in Colonial Rarh Bengal', in Nupur Dasgupta and Amit Bhattacharyya (eds.), Essays in History of Science, Technology and Medicine, Setu, Kolkata, 2014, pp. 170-2.

${ }^{25}$ One Jawaharlal Dhar, self-made electrician, actively participated in the electric installation project of the Old Howrah Bridge. Later, he involved in the electrification of the Eden Gardens also. The major invention of this self-styled engineer was the safety-door lock for which he received the patent right from the government. He also invented a machine to generate solar electricity. Jawaharlal Dhar, Sachitra Kolikata-Rahasya, Paraspathar, Reprint Volume, Kolkata, 2012 (First Published in 1896). 
and Malek, the Indian technicians employed by Bose to build his instruments. Without documenting the contributions of the unsung viśvakarmās, Sidhartha Ghosh emphasized long back, the process of adaptation and appropriation of Western technology cannot be understood comprehensively. Perhaps it is time for the historians of South Asia to address these issues centrally, write a 'bottom-up' if not altogether alternative history of technology than they have done before.

\section{Acknowledgment}

Originally presented at a seminar, 'Historiography of Science in India', INSA, New Delhi (24-25 September 2018), I am grateful to Professor Ishrat Alam and INSA for the opportunity. I particularly benefitted from the comments of Professor Sujata Mukherjee, Professor Arnab Rai Choudhuri, Professor Arabinda Samanta, and Dr. Aparajith Ramnath. My mentor, Professor Deepak Kumar, commented on various versions of this essay and suggested crucial modifications. I remain grateful to Professor Ross Bassett, Professor Tirthankar Roy and Dr. Prakash Kumar for their sustained encouragement. I also thank the anonymous referee for her/ his insightful comments. Mr. Madhvendra Narayan, as usual, has been a wonderful editor.

\section{Bibliography}

\section{A. Primary Sources}

[1] Contemporary Bengali Journals - Amrita Bazar Patrika, Arthik Unnoti, Banik, Bharati, Masik Basumati, Nabyabharat, Prabasi, Sadharani, Sahitya Parishad Patrika, Sulav Samachar, Tattobodhini Patrika.

[2] Contemporary English Journals-The Calcutta Municipal Gazette, The Statesman

\section{B. Contemporary Texts}

[3] Bagal Jogesh Chandra. Jatiyatar Nabamantra O Hindu Melar Itibritta, Salil Kumar Mitra, Calcutta, 1945.
[4] Bose P. N. National Education and Modern Progress, Kar, Majumder \& Co., Calcutta, 1921.

[5] Moitra Kalidas. Baspiya Kal O Bharatiya Railway: The Steam Engine and the East Indian Railway containing a History of India, Editor, J. H. Peters, Serampore 1855 .

[6] Moitra Kalidas. Electric Telegraph ba Taritbartabaha Prakaran, Editor: J. H. Peters, Serampore, 1855.

[7] Moitra Kalidas. Manabdehotatwa or the Human Frame: An Essay and Familiar Introduction to the Principles of Anatomy and Physiology, Editor: J. H. Peters, Serampore, 1855.

[8] Ray Jogesh Chandra. Deshe Vijnan-Pratistha, Prabasi, 15.1, Baisakh 1322 B. S. (1915): 127-41.

[9] Ray Jogesh Chandra. Ranjita O Chritrita Bastra, Nabyabharat, 10.4, Sraban 1299 B. S. (1892): 177183.

[10] Ray Jogesh Chandra. Sahitya Parishad Patrika, 21. 2, 1321 B. S. (1914): 81-96.

[11] Ray Jogesh Chandra. Vidyanidhi, 'Kala-Siksha', Bharati, 26, Kartik and Agrahayan 1309 B. S. (1902): 674-687; 760-771.

[12] Samaddar Jogindra Nath. Sitanath Ghosh, Prabasi, 13.2, 1319 B. S. 1912.

[13] Sarkar Benoy Kumar. Education for Industrialization: An Analysis of Forty Years of Jadavpur College of Engineering and Technology, 1905-45, Chuckervertty, Chatterjee \& Co, Calcutta, 1946.

[14] Smith George. The Life of William Carey: ShoeMaker and Missionary, Everyman's Library, Calcutta, 1885.

\section{Secondary Sources}

[15] Anderson Robert S. Nucleus and Nation: Scientists, International Networks and Power in India, The University of Chicago Press, Chicago and London, 2010.

[16] Bernal J. D. Science in History, Watts, London, 1954. 
[17] Chattopadhyay Arabinda. Jogesh Chandra Ray Vidyanidhi, Bangiya Sahitya Parishad, Kolkata, 2009.

[18] Choudhury Deep Kanta Lahiri. Telegraphic Imperialism: Crisis and Panic in the Indian Empire, c. 18301920, Palgrave Macmillan, Basingstoke, 2010.

[19] Chowdhury Indira. Growing the Tree of Science: Homi Bhaba and the Tata Institute of Fundamental Research, Oxford University Press, New Delhi, 2016.

[20] Das Gupta Anil Chandra (ed.). The Days of the John Company: Selections from Calcutta Gazette 1824-1832,West Bengal Government Press, Calcutta, 1959.

[21] Dasgupta Subrata. Judging scientific creativity: the case of the early Jagadis Bose, Indian Journal of History of Science, 53.4 (2018): T60-T67.

[22] Dhar Jawaharlal. Sachitra Kolikata-Rahasya, Paraspathar, Reprint Volume, Kolkata, 2012.

[23] Dutta Achintya Kumar. Indigenous Technique and Artisanal Works: Blacksmiths of Rarh Bengal, in Nupur Dasgupta and Amit Bhattacharya (eds.), Essays in History of Science, Technology and Medicine, Setu Prakashani, Kolkata, 2014, pp. 159-191.

[24] Ghosh Hemendra Prasad. Shiv Chandra Nundy, Masik Basumati, Kartik, 1360 B. S. 1953: 107-114.

[25] Ghosh Amitabha. Some eminent Indian pioneers in the field of technology, Indian Journal of History of Science, 29.1(1994): 63-75.

[26] Ghosh Sidhartha. Karigari Kalpana O Bangali Udyog, Dey’s, Kolkata, 1988.

[27] Guha Ranajit. On Some Aspects of the Historiography of Colonial India, in Guha (ed.). Subaltern Studies I, Oxford University Press, New Delhi, 1982.

[28] Hardiman David and Mukherji Projit Bihari (eds.). Medical Marginality in South Asia: Situating Subaltern Therapeutics, Routledge, London and New York, 2012.

[29] Kumar Deepak. Science and the Raj: A Study of British India, Oxford University Press, Second Edition, New Delhi, 2006.
[30] Mukhopadhyay Troilokkyanath. Damru-Charit, New Age Publisher Pvt. Ltd, Fifth Edition, Kolkata, 2009.

[31] Nandy Ashis. The Traditions of Technology, A Very Popular Exile, Oxford India Paperbacks, New Delhi, 2010.

[32] Palit Chittabrata. Scientific Bengal: Science, Technology, Medicine and Environment under the Raj, Kalpaz, Delhi, 2006.

[33] Phalkey Jahnavi. Atomic State: Big Science in Twentieth Century India, Permanent Black, Ranikhet, 2013.

[34] Plys Kristin. Subaltern Historiography, the Working Class, and Social Theory for the Global South, Economic \& Political Weekly,. 54.43, 26 October 2019.

[35] Raina Dhruv and Habib S Irfan. Domesticating Modern Science: A Social History of Science and Culture in Colonial India, Tulika, New Delhi, 2004.

[36] Ramnath Aparajith. The Birth of an Indian Profession: Engineers, Industry and the State, 1900-47, Oxford University Press, New Delhi, 2017.

[37] Ramaswamy Vijaya (ed.). In Search of Viswakarma: Mapping Indian Craft Histories, Primus, New Delhi, 2019.

[38] Ray Jogesh Chandra. Atmajebani, Anandakumar Roy, Bankura, 2002.

[39] Sarkar Smritikumar. Technology and Rural Change in Eastern India 1830-1980, Oxford University Press, New Delhi, 2014.

[40] Sarkar Suvobrata. The Quest for Technical Knowledge: Bengal in the Nineteenth Century, Manohar, New Delhi, 2012.

[41] Sarkar Suvobrata. Let There Be Light; Engineering, Entrepreneurship and Electricity in Colonial Bengal, 1880-1945, Cambridge University Press (forthcoming), Cambridge and New Delhi.

[42] Shridharani Krishnalal. Story of the Indian Telegraph: A Century of Progress, Post \& Telegraph Department, New Delhi, 1953. 